\title{
Long-Term Teacher Orchestration of Technology-mediated Collaborative Inquiry
}

\section{Viilo, Marjut}

2018

Viilo , M , Seitamaa-Hakkarainen , P \& Hakkarainen, K 2018 , ' Long-Term Teacher

Orchestration of Technology-mediated Collaborative Inquiry ', Scandinavian Journal of

Educational Research , vol. 62 , no. 3 , pp. 407-432 . https://doi.org/10.1080/00313831.2016.1258665

http://hdl.handle.net/10138/309234

https://doi.org/10.1080/00313831.2016.1258665

unspecified

acceptedVersion

Downloaded from Helda, University of Helsinki institutional repository.

This is an electronic reprint of the original article.

This reprint may differ from the original in pagination and typographic detail.

Please cite the original version. 


\section{Long-term teacher orchestration of technology-mediated collaborative inquiry}

Marjut Viilo $^{1 *}$, Pirita Seitamaa-Hakkarainen ${ }^{1}$, \& Kai Hakkarainen ${ }^{2}$

${ }^{1}$ Department of Teacher Education, University of Helsinki, P.O. Box 8, 00014 University of Helsinki, Finland marjut.viilo@helsinki.fi,pirita.seitamaa-hakkarainen@helsinki.fi,

${ }^{2}$ Institute of Behavioural Sciences, University of Helsinki,

P.O. Box 9, 00014 University of Helsinki, Finland, kai.hakkarainen@helsinki.fi 
Abstract

This explorative case study longitudinally examines teacher orchestration of an inquiry learning process in a technology-enhanced elementary classroom. A 13month investigative study on cultural artifacts was conducted on 32 fourth grade students who progressed to the fifth grade during the project. The activities were mediated and documented using Knowledge Forum, a technology-enhanced collaborative environment. Data were gathered from video recordings of whole-class sessions and the teacher's reflective diary entries. The coding scheme for the video analysis focused on identifying the various orchestration events, while drawing on theory and data-driven qualitative content analysis. Six types of orchestration events effectively maintained the process during whole-class sessions. These events supported the advancement of knowledge, reflection on inquiry, and pragmatic organization of inquiry. The study also adopted CORTDRA diagrams that highlighted temporal aspects of the orchestration events throughout the project. Knowledge Forum enabled the longitudinal advancement of the project.

Keywords: collaborative learning, elementary school, inquiry learning, progressive inquiry, teacher orchestration, technology-enhanced learning 
Teacher's longterm orchestration of collaborative inquiry

\section{Introduction}

Collaborative inquiry learning and associated practices to engage students in building and creating knowledge are among the most promising methods to support in-depth learning, especially when supported with technology (Hmelo-Silver, Duncan, \& Chinn, 2007; Littleton, Scanlon, \& Sharples, 2012; Paavola \& Hakkarainen, 2005; Scardamalia, 2002). This approach to collaborative inquiry and knowledge creation is drawing the attention of many educators. It involves challenging students to assume responsibility for the investigative process by, for example, posing questions or generating working theories (Scardamalia, 2002; Scardamalia \& Bereiter, 2006; Zhang et al., 2011). However, in several cases, efforts to implement inquiry learning have collided with the existing structures of classroom learning (Bielaczyc, 2013; Chan, 2011; Hakkarainen, 2009). For example, time limitations have hindered the fluent implementation of projects or classroom practices do not easily transform into the intended collaborative inquiry learning (Roth, 2002). In settings where the process and object of inquiry are designed in collaboration with students, the outcome of an inquiry cannot be fully known beforehand; this also applies to the phases of the process and content to be studied. Thus, when teachers aim to implement collaborative inquiry, they must learn to acknowledge uncertainty and be open, while simultaneously providing sufficient structuring and guidance. Although students need support and advice to become active participants in the collective inquiry process, excessive structuring and direction may undermine their epistemic agency.

In addition to the above challenges, an understanding of the teacher's perspective of the actual classroom practices that compose the long-term orchestration of collaborative inquiry processes is essential. We do not yet know enough of what teachers do in the classroom while implementing technology-enhanced inquiry learning (Greiffenhagen, 2012). Although studies have been carried out on teacher practices of guiding here-and-now classroom interactions (Mäkitalo, Jakobsson, \& Säljö, 2009; Stahl, 2006), few detail the challenges of guiding inquiry projects throughout an entire academic year (Dillenbourg, 2015; Mercer, 2008; Viilo et al., 2011). This is critical to understanding the long-term trajectories of classroom practices and the temporal flow of events, which generally involve multi-faceted topics and heterogeneous 
Teacher's longterm orchestration of collaborative inquiry

activities (Littleton \& Kerawalla, 2012; Mercer, 2008). Here, we examine a teacher's long-term orchestration of collaborative inquiry, essential in collaborative inquiry learning, and report our findings on a collaborative technology-mediated inquiry project conducted at an elementary school. In this study, collaborative inquiry learning is a pedagogical approach based on the ideas of knowledge building (Scardamalia \& Bereiter; 2006) and progressive inquiry (Hakkarainen, 2003), where the aim is to enrich the participants' initial knowledge and understanding through collaboration. This kind of collaborative knowledge creation nevertheless demands teacher facilitation in order to support learning through inquiry (Bybee, 2000; NRC, 2012). Using video data and the teacher's reflective diary notes, we analyze how the teacher, with the support of Knowledge Forum, orchestrated sustained collaborative inquiry practices by structuring and organizing the collective activities of the learning community.

First, we outline the challenges in orchestrating inquiry learning, followed by a discussion of the teacher's role in mediating the longitudinal process using corresponding knowledge practices. Next, we describe the context of our study and the methods used to collect and analyze data. Finally, we discuss our findings and their implications.

\section{Challenges in orchestrating long-term inquiry learning}

Teachers who aim to implement collaborative learning and knowledge creation often encounter difficulties when seeking to create corresponding practices in their classrooms (Bielaczyc, 2013; Chan, 2011; Hakkarainen, 2009). Several instructional and pedagogical approaches exist, wherein the level of structure and prescription varies from highly specified procedures to emergent practices developed in collaboration with students (Zhang et al., 2011; see also Sawyer, 2011). The design of learning activities is often based on pre-set procedures (e.g., pre-established scripts and structures embedded in curriculum material) that constrain and determine the implementation of the learning setting (Dillenbourg \& Jermann, 2007; Kirschner, Sweller, \& Clark, 2006). However, Zhang et al. (2011) emphasized principle-based approaches, such as knowledge building, that define the guiding principles of a learning approach and allow greater flexibility by relying on educational opportunities emerging from various learning situations (Zhang et al., 2011). Accordingly, discourse on classroom inquiry reveals a tension between researchers that highlight the importance of pre-set procedures (e.g., Kirschner, Sweller, 
Teacher's longterm orchestration of collaborative inquiry

\& Clark, 2006) and those emphasizing emergent practices (Hong \& Sullivan, 2009; Scardamalia \& Bereiter, 2006; Zhang et al., 2011). However, according to Sawyer (2004; 2011; see also Roth, 2002), the practical implementation of emergent collaborative learning requires teachers to balance the structuring of a project with a flexible response to the ideas and practices that emerge through collaboration.

While we use the concept of "orchestration" as a metaphor for defining the teacher's deliberate efforts as an agent in designing, planning, managing, and enacting collaborative inquiry processes (Littleton, Sharples, \& Scanlon, 2012), the computer-supported collaborative learning (CSCL) community is still far from consensus on the definition of orchestration (Dillenbourg, 2013; Roschelle, Dimitriadis, \& Hoppe, 2013). The concept draws on the metaphor of a teacher functioning as a conductor, which is analogous to a conductor accommodating the interplay of musicians in an orchestra. The metaphor covers both the prior arrangement of a performance and the dynamic management of people and activities to achieve certain productive results (Sharples \& Anastopoulou, 2012). Thus, we crucially acknowledge the two meanings of orchestration, "orchestration design" and "dynamic orchestration" (Sharples \& Anastopoulou, 2012).

Orchestration design refers to pedagogical scenarios that describe the organization of learning to model sequences of learning activities from a particular time and event, as well as from participant perspectives (Dillenbourg, 2015). Orchestration graphs (who does what and when) resemble algorithms that make pre-planned educational activities visible (Dillenbourg, 2015). However, the more explicit the educational structure, the less opportunity there is for spontaneous teaching (Sharples \& Anastopoulou, 2012). By contrast, dynamic orchestration captures a teacher's multilayered work across multiple learning activities supported by technology-enhanced learning. This could describe, for example, individual, social, toolmediated, and changing learning situations (Dillenbourg, 2013; Dillenburg, Järvelä, \& Fischer, 2009). Dynamic orchestration focuses on the need for teachers to have a bird's eye view of simultaneous, ongoing activities occuring on different planes: individual, group, and the class as a whole (Dillenburg, Järvelä, \& Fischer, 2009; Sharples \& Anastopoulou, 2012). In addition, Looi and Song (2013; also, Song \& Looi, 2012) emphasize the unplanned aspects of enacted 
Teacher's longterm orchestration of collaborative inquiry

activities. They argue that a teacher's skills and pedagogical understanding are crucial to productively coping with unpredictable classroom situations.

Dynamic orchestration has also been explored in relation to improvisational classroom teaching (Sawyer, 2004; Sharples \& Anastopoulou, 2012). According to Sawyer (2004; 2011), guiding an emergent collaborative inquiry process requires disciplined improvisation. Such an approach treats collaborative learning as a shared social activity wherein all participants manage the collective process, not only the teacher (Sawyer, 2004). For example, instead of asking factbased questions or evaluating a given answer, the teacher encourages students to provide various types of solutions or ideas to facilitate collaborative improvisation. Despite the freedom offered, the teacher must guide the collective process to ensure that learning objectives are met (Sawyer, 2011).

"Discipline" refers to aspects of the pedagogical framework that a teacher considers to be more or less fixed (e.g., good practices that students have already mastered) and "improvisation" involves novel aspects and activities that a teacher hopes will be achieved by exploring fluid or unexpected opportunities (Beghetto \& Kaufman, 2011). The interpretation of disciplined improvisation is not only momentary spontaneity, but also the unplanned spaces between the planned and implemented curriculum, as well as planned openings in particular lessons that provide opportunities for the unexpected (Beghetto \& Kaufman, 2011).

Improvisation requires attention to the needs and ideas of students (Barker \& Borko, 2011) and willingness to share control of an activity when appropriate. In addition, Beghetto and Kaufman (2011) point out that an emergent process not only focuses on momentary classroom discussions, but is also based on the teacher's broader decisions to use structured plans and routines versus reliance on partially improvised practices.

Thus, rather than the mere here-and-now management of discourse interactions, this study focuses on the long-term orchestration of inquiry activities, specifically a teacher's efforts to structure and organize inquiry activities that enable the class to reach the objectives of the inquiry project.

\section{Mediating inquiry}




\section{Teacher's longterm orchestration of collaborative inquiry}

Orchestrating collaborative inquiry can be achieved through deliberate but flexible structuring and systematic guiding. However, as Sawyer (2004) and several others (Barker \& Borko, 2011; Erickson, 2011) have underscored, improvisation and co-constructive processes can work only if participants have internalized several patterns and routines of shared inquiry. Supporting student generation of independent ideas and promoting collaboration within a classroom community is impossible without a developed classroom culture, practices, and specification of social and technological tools that can support and channel students' activities (Bielaczyc, 2006; Zhang et al., 2011). In collaborative inquiry learning, the use of a networked learning environment often offers the tools to organize learners' inquiry practices and activities based on shared objects (Lonchamp, 2012). However, educational technologies must be integrated with social practices enacted by the students and teacher (Hakkarainen, 2009; Ritella \& Hakkarainen, 2012). Although software such as Knowledge Forum (hereinafter KF) supports co-constructive processes and the creation of shared knowledge (Lonchamp, 2012), a teacher is still required to establish productive routines and practices. To this effect, a teacher's efforts are critical: they cultivate shared practices that channel collective work in a way that elicits inquiry.

Students can participate in a knowledge-creating inquiry only when they are deliberately guided to follow corresponding practices (Hakkarainen, 2009). A teacher is needed to facilitate the deepening of inquiry, deal with the pragmatic organization and management of project work, support social relationships and build communities, and sustain reflection on the shared inquiry. These kinds of knowledge practices can be characterized as epistemic, reflective, or sociopragmatic (Beguin \& Rabardel, 2000; Rabardel \& Beguin, 2005; Ritella \& Hakkarainen, 2012). Knowledge building and theories of collaborative inquiry have strongly addressed the importance of epistemic mediation (Ritella \& Hakkarainen, 2012) by emphasizing how collective tools assist learning community members to externalize their thinking through texts or other representations as well as make their ideas and the knowledge sought available to others (Hakkarainen, 2003; Lonchamp, 2012). Beyond epistemic mediation, Rabardel and Beguin (2005; also Beguin \& Rabardel, 2000) distinguished other kinds of processes: mediating practices using collaborative technologies, i.e., "reflective mediation" and "socio-pragmatic mediation” (Beguin \& Rabardel, 2000; Ritella \& Hakkarainen, 2012). These two categories will 
Teacher's longterm orchestration of collaborative inquiry

be used here. The former includes shared reflection to guide advancement of an inquiry and the latter relates to coordinated efforts in building communities and interactions around the shared knowledge-creation objectives, as well as organizing and managing the knowledge creation processes.

The present study longitudinally examines The Artifact Project, which was mediated by $\mathrm{KF}$ and conducted in an ordinary elementary classroom in Finland. Using data from video recordings of whole-class activities and the teacher's reflective diary notes, the study analyzes how the teacher orchestrates a longitudinal inquiry learning process. We address the following research questions:

1. What are the types of orchestration events and processes utilized by the teacher to maintain longitudinal collective inquiry learning?

2. How did the collaborative learning environment (i.e., Knowledge Forum) support and mediate the collective inquiry process?

\section{Method}

\section{Study participants and setting}

The Artifact Project ("The Past, Present, and Future of Artifacts") was designed as a qualitative case study, both explorative and longitudinal in nature (Saldana, 2009; Yin, 1994). The research was conducted at an ordinary elementary school and aimed at restructuring classroom practices toward collaborative progressive inquiry practices by creating a community with shared learning and inquiry goals. The key objective was to engage students in building and creating knowledge about cultural artifacts by collaboratively constructing their own conceptual and material artifacts relating to the topic (e.g., documents, visualizations, and models of designed objects) (Seitamaa-Hakkarainen, Viilo, \& Hakkarainen, 2010). The project was designed by researchers and the class teacher, and took place in her classroom in Laajasalo Elementary School, Helsinki, Finland, from 2003 to 2004. The teacher had previously completed a long series of inquiry projects and acted as the regional ICT support teacher. A total of 32 students participated in the project. At the beginning of the project, all students were 10 years old. The project covered around 139 lessons (the duration of each lesson was 45 minutes) across 
Teacher's longterm orchestration of collaborative inquiry

three terms and integrated school subjects such as history, Finnish, science, design, and technology. Figure 1 illustrates the main phases and activities of The Artifact Project.

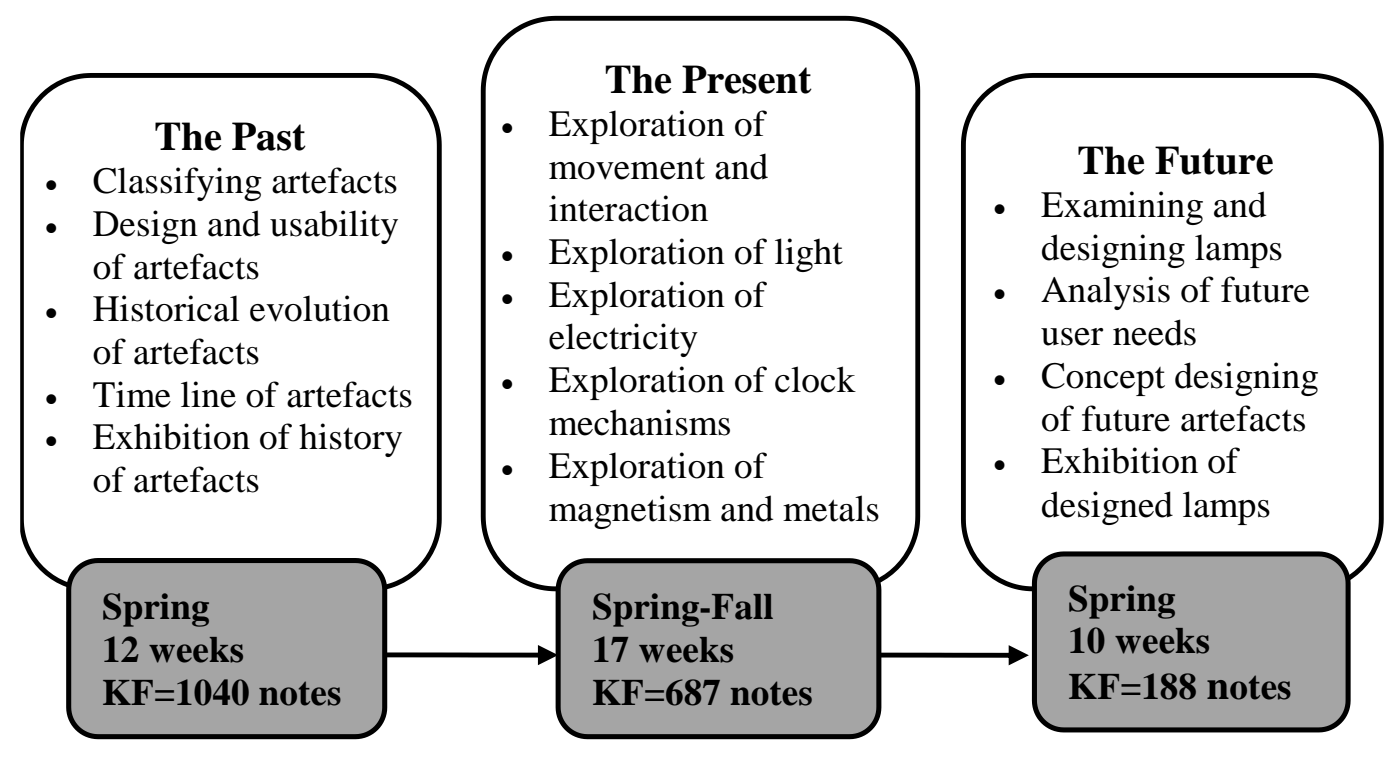

Figure 1. Phases and activities of The Artifact Project

The Artifact Project commenced in the second term of fourth grade and lasted three terms (or 13 months) until the end of fifth grade. The entire classroom was engaged in planning and conducting the project. The students worked in teams throughout the project and student combinations varied at different stages. Minimal work was done individually (e.g., listing artifacts that a student had personally used during the day). The teacher had introduced the progressive inquiry approach (Hakkarainen, 2003) to the students in the fall, during their first term, by conducting a small project.

The present project began with discussions about progressive inquiry with the students and their ideas about appropriate collaborative investigations. The aim was to encourage the students to come up with their own ideas about how to study artifacts and, with the teacher, design various learning activities and field trips. The researchers and teacher together designed the general theme and associated pedagogical infrastructure for the project, but the actual project design emerged through student-teacher interaction without strict, pre-determined plans. The 
Teacher's longterm orchestration of collaborative inquiry

stages of the project were based on previous ones and the students' ideas of what and how they would like to study. Although the present investigators and teacher had regular planning sessions throughout, the latter was responsible for revising and adapting plans in practice.

The project challenged the students to analyze everyday handheld artifacts within their cultural contexts. The aim of the project was to provide students with an authentic and meaningful context for studying the historical evolution of artifacts, to engage students in designbased science learning (Fortus \& al., 2004), and to familiarize them with design practices. Observing and examining the historical evolution of artifacts offers an understanding of how and why these objects respond to our needs and are designed in a given way. Before the actual project began, the teacher created the foundation for the longitudinal project. The students were introduced to inquiry practice and new supportive tools through activities that supported questioning, hypothesizing, and explaining by asking them to explore artifacts in their environment and analyze their functionalities. They also learned to use the new learning environment (software), Knowledge Forum.

In the first phase of the project, The Past, a historical investigation of artifacts and their functionalities was conducted. An understanding of the diversity of artifacts provided the basis for invention and improvement of these artifacts. The Past phase included 53 lessons. For the historical investigation, each student team chose a type of handheld artifact they found interesting, that is, a ball, clock, lamp, spoon, jewelry, lock and key, and money. The students' ideas drove the investigation into the past of the selected artifacts. They visited museums and set up an exhibition of the studied artifacts, which also included interviews with relatives about their memories of a particular object. The historical inquiries of these items led the students toward the second phase of the project, The Present, which comprised 44 lessons. During this phase, the students explored scientific phenomena related to the chosen artifacts, such as the movement of a ball, the functioning of a lamp and light, and the characteristics of metals. They were guided to ask questions and perform their own scientific experiments as well as those based on already available science kits. The third phase of the project, The Future, was conducted under the shared leadership of a professional designer and the teacher. The participants designed lamps and other future artifacts. While designing, students were creating conceptual (what it does), technical 
Teacher's longterm orchestration of collaborative inquiry

(how it works), aesthetic (how it looks) and constructional (how parts fit together) solutions (Barlex, 2007). The design process was conducted in teams, which involved sketching, drawing, and building prototypes or models. The Future phase extended over 42 lessons.

The technical infrastructure of the project was provided by KF, which is designed to support collaborative knowledge building and the sharing of knowledge (Scardamalia, 2002; Scardamalia \& Bereiter, 2006). KF is essentially a database consisting of knowledge created and organized by the students and the teacher; it allows visual organization when creating an interlinked series of views (background pictures with computer notes). By authoring notes, the students contribute ideas, theories and reference materials, to views, which are workspaces for various streams of inquiry. The synthesis of knowledge is encouraged by several supportive tools that allow students, for instance, to build on, or annotate their fellow students' notes or create rise above notes for synthesizing a completed inquiry. When a database is in active use, KF saves all stages of the participants' inquiry, presenting the collectively created cumulative process. During The Artifact Project, 30 views and more than 1,000 notes were created in the KF database. In addition to text, the views and notes contained large quantities of visual data, such as sketches, drawings, and photographs.

\section{Data collection and analysis}

This case study is based on video data and materials in the teacher's reflective diaries, all of which were collected during the longitudinal study project. The teacher entered data in the project diary template several times per week throughout the project. The diary entries included a structured part wherein the teacher described classroom activities (e.g., time frame, location, and social organization of activities) and a reflective part where the teacher wrote her own impressions of the process. The aim was to support the teacher in reflecting on her teachings in a systematic manner. The template called for reflection on the organization of practices, development of inquiry, functioning of the community, and role of technology in supporting the process. In this study, we use the teacher's reflections in a descriptive manner to depict her background reflections of the ongoing project phases.

In total, we filmed 56 lessons revealing classroom practices. Approximately one-third of the lessons from the first two project phases, the Past and Present, were recorded. We excluded 
Teacher's longterm orchestration of collaborative inquiry

the Future phase from the video data, because the professional designer was primarily responsible for guiding the students' design process (see Kangas, Seitamaa-Hakkarainen, \& Hakkarainen, 2013). In addition, we excluded 12 lessons that involved, for instance, a parents' evening, museum visits, and exhibition openings. Since we had limited video recording resources, the rationale underlying the selection of the sessions was based on researcher-teacher negations over various project activities: we recorded sessions that the teacher viewed as crucial to starting a new activity or sessions that systematically covered important aspects of the project (sessions involving teamwork or the whole class). The teacher's diary provided descriptions of activities not included in the video data. Further, with the help of the teacher's structured diaries, we discovered that the episodes filmed with the whole class accurately represented unrecorded activities involving the whole class.

The videotaped activities from the Past and Present phases were divided into episodes (f =34) considered distinguishable when the type of activity (e.g., planning and discussing an idea) or social organization (whole class, team, and independent work) changed. The purpose of this rough episode-level analysis was to identify data relevant (i.e., sessions with the whole class) to our examination of the long-term orchestration process (Ash, 2007; Derry et al., 2010; Klette, 2009; Lehesvuori, Viiri, Rasku-Puttonen, Moate, \& Helaakoski, 2013). We analyzed all episodes with the whole class to depict how the teacher, along with the students, conducted the project. We also examined teamwork episodes, which generally took place between joint episodes. The analysis revealed that during the teamwork sessions, the teacher would go around the class (see also Greiffenhagen, 2012) mainly repeating previously given instructions and encouraging teamlevel collaboration. All strategic guidance of the longitudinal project was delivered during episodes involving the class as a whole, and these episodes were consequently our focus. Table 1 presents part of the episode-level categorization of the video data. 
Teacher's longterm orchestration of collaborative inquiry

Table 1. Selected time span of recorded episodes and data analysis.

\begin{tabular}{|c|c|c|c|c|}
\hline \multirow[b]{2}{*}{$\begin{array}{c}\text { Stages of the } \\
\text { project }\end{array}$} & DATA & \multicolumn{2}{|c|}{ Episode level of analysis } & \multirow{2}{*}{$\begin{array}{c}\begin{array}{c}\text { Event level analysis of } \\
\text { orchestration }\end{array} \\
\begin{array}{c}\text { (See CORDTRA diagrams } \\
\text { in detail) }\end{array}\end{array}$} \\
\hline & The videotaped episodes & $\begin{array}{c}\text { Social } \\
\text { organization } \\
\text { of episodes }\end{array}$ & $\begin{array}{l}\text { Type of } \\
\text { activity }\end{array}$ & \\
\hline \multirow{17}{*}{$\begin{array}{l}\text { The physical } \\
\text { phenomena of } \\
\text { light }\end{array}$} & \multirow[t]{4}{*}{$\begin{array}{l}24 \text { Organizing working theories, } 31 \\
\text { min }\end{array}$} & \multirow[t]{4}{*}{ Whole class } & Planning & $\begin{array}{l}\text { Recollecting previous inquiry } \\
\text { activities }\end{array}$ \\
\hline & & & & Discussing deepening inquiry \\
\hline & & & & Discussing ideas \\
\hline & & & & Practical management of activity \\
\hline & 25 Organizing working theories $27 \mathrm{~min}$ & Team & & \\
\hline & \multirow[t]{6}{*}{$\begin{array}{l}26 \text { Urging in creating deepening } \\
\text { working theories and questions, } 10 \mathrm{~min}\end{array}$} & \multirow[t]{6}{*}{ Whole class } & $\begin{array}{l}\text { Discussing } \\
\text { ideas }\end{array}$ & $\begin{array}{c}\text { Recollecting previous inquiry } \\
\text { activities }\end{array}$ \\
\hline & & & & Practical guidance of inquiry \\
\hline & & & & Assessing the advancement of inquiry \\
\hline & & & & Discussing ideas \\
\hline & & & & Practical guidance of inquiry \\
\hline & & & & Practical management of activity \\
\hline & $\begin{array}{l}27 \text { Creating deepening working } \\
\text { theories } 35 \mathrm{~min}\end{array}$ & Team & $\begin{array}{l}\text { Discussing } \\
\text { ideas }\end{array}$ & \\
\hline & \multirow[t]{4}{*}{28 Starting to do experiments, $14 \mathrm{~min}$} & \multirow[t]{4}{*}{ Whole class } & Planning & Practical management of activity \\
\hline & & & & Practical management of activity \\
\hline & & & & Discussing ideas \\
\hline & & & & Practical guidance of inquiry \\
\hline & 29 Doing experiments, $65 \mathrm{~min}$ & Team & & \\
\hline \multirow{6}{*}{$\begin{array}{l}\text { The physical } \\
\text { phenomena of } \\
\text { force }\end{array}$} & \multirow{5}{*}{$\begin{array}{l}30 \text { Connecting electricity toolkit } \\
\text { experiment to earlier student questions, } \\
\text { setting the experiment, } 11 \mathrm{~min}\end{array}$} & \multirow[t]{5}{*}{ Whole class } & $\begin{array}{c}\text { Discussing } \\
\text { ideas }\end{array}$ & $\begin{array}{l}\text { Recollecting previous inquiry } \\
\text { activities }\end{array}$ \\
\hline & & & & $\begin{array}{l}\text { Recollecting previous inquiry } \\
\text { activities }\end{array}$ \\
\hline & & & & Assessing the advancement of inquiry \\
\hline & & & & Practical management of activity \\
\hline & & & & Practical guidance of inquiry \\
\hline & 31 Doing experiment $30 \mathrm{~min}$ & Team & & \\
\hline
\end{tabular}

To examine the teacher's orchestration of the inquiry process, we continued our analysis of the episodes with the whole class at a more detailed level (see Table 1). We did not focus on teamwork, group interaction, collaboration, and other social aspects of inquiry that have already been intensively studied in the field of learning sciences and CSCL (Mercer \& Littleton, 2007; Stahl, 2006). The qualitative content analysis focused on identifying those issues relevant to how the teacher maintained shared activities. A coding scheme was created to address the overall form of the shared activities. Such coding schemes require interpretation on the part of the coders (Angelillo, Rogoff, \& Chajavay, 2007). A combination of theory-based and data-driven approaches was used to develop the coding frameworks (cf. Saldaña, 2009; Klette, 2009); these 
Teacher's longterm orchestration of collaborative inquiry

were created on the basis of preliminary analyses of data as well as reflections on the data in relation to the theoretical outlining of the present study (cf. Seale, 2006). Qualitative content analysis was systematically employed using ATLAS/ti software (Chi, 1997; Friese, 2012; Kelle, 2006; Klette, 2009) and focused on recognizing the teacher's orchestration events ( $f=123)$. Six types of orchestration events were identified from the video data: (1) discussing ways of deepening inquiry (e.g., collaboratively developing a research plan) (2) discussing inquiry ideas (e.g., discussing electricity and current) (3) recollecting previous inquiry activities (e.g., evaluating aspects from the KF lock-and-key view that could be used as a basis for working in the next phase) (4) assessing the advancement of inquiry (e.g., jointly reflecting on an ongoing situation in relation to advancing light experiments) (5) practical guidance of inquiry (e.g., asserting the importance of speaking in turns), and (6) practical management of activities (e.g., physical arrangements of work). Extracts from the different types of orchestration events are given in Appendix 1.

These orchestration events can be seen as recurring epistemic routines or inquiry practices that structured the participants' joint activity. Under the teacher's guidance, the students dealt with various challenges, unforeseen obstacles, and enacted situations (Beghetto \& Kaufman, 2011; Erickson, 2011; Sawyer, 2011; 2009). To ensure credibility in interpreting the results, we used both researcher and data triangulation (Cohen, Manion, \& Morrison, 2007). We cross-checked our interpretations with accurate definitions of categories and by examining the inter-coder reliability of classifications (Cohen's kappa). The inter-coder reliability coefficient for the classification of the episodes into six types was .85 (Cohen's kappa), which was regarded as acceptable. The teacher's reflective diaries together with the video data ensured validated interpretations (i.e., data triangulation).

Next, we focused on the role of KF during the orchestration events and created a parallel coding scheme (Klette, 2009). We did so by answering the following questions: Was KF the collective basis for working when the inquiry results were projected on a shared screen for reference and discussion? Was KF the concrete developing object in their inquiry when the class collectively discussed and developed ideas and plans, and the shared screen was used to 
Teacher's longterm orchestration of collaborative inquiry

externalize their ideas visible in real time? Was KF not in use? The inter-coder reliability coefficient for classifying the episodes into three categories was .94.

In this longitudinal qualitative case study, we used a data visualization technique (chronologically oriented representations of discourse and tool-related activity [CORDTRA] diagrams) to provide a temporal account of the relationships among the various orchestration events and the use of KF (Hmelo-Silver, 2003; Hmelo-Silver et al., 2008). Hmelo-Silver and colleagues $(2008,2009)$ proposed the use of CORDTRA diagrams to obtain information on multiple coded data over time. Luckin et al. (2001) originally developed the technique for the single-learner context, which Hmelo-Silver et al. (2009) then further refined for use with teams and technology-mediated learning. They used CORDTRA diagrams to support an analysis that extends beyond coding individual speech acts by visualizing discourse structures and the usage of helping tools (Hmelo-Silver et al., 2008, 2009).

In this study, we used an orchestration event as the unit of analysis in the CORDTRA diagrams, where the two coding schemes (i.e., six types of orchestration events and use of KF) were graphically represented side by side on a single timeline. In practice, we created the diagrams as scatter plots, using an Excel spreadsheet to trace the rhythmic recurrence of the orchestration events across the longitudinal project. The diagram represents the video-recorded orchestration events chronologically. This kind of visualization can be rationalized through temporality; the graph depicts the trajectory of activities (Mercer, 2008), recognizing both the historical and the dynamic qualities of time (Lehesvuori et al., 2013). According to several researchers (Hmelo-Silver et al., 2009; Lemke, 2000), visual representations are needed for understanding the processes involved in sociotechnical systems - who is participating, what participants are actually doing, and how participants and actions are related. As Lehesvuori and colleagues (2013) emphasized, without the visualization of the chronological dimension of learning, the data analysis would be limited to the description of the categories used.

\section{Results}

When analyzing the sessions with the whole class, we concentrated on the teacher's active efforts to guide the inquiry across various activities. We focused on examining the unfolding of events and how these supported the ongoing activities. Our analysis indicated that 
Teacher's longterm orchestration of collaborative inquiry these episodes comprised six types of orchestration events that served various functions in advancing the inquiry activity at hand and were present in different combinations in each wholeclass episode. These six types of orchestration events fell under three categories. The first two types appeared to relate to epistemic mediation, the third and fourth to reflective mediation, and the fifth and sixth to socio-pragmatic mediation, as outlined in the introduction (Rabardel \& Beguin, 2002). Table 2 depicts the interrelation of the epistemic, reflective, and pragmatic aspects of inquiry; orchestration events; and the role of KF.

Table 2. Association between orchestration events, aspects of inquiry, and role of KF.

\begin{tabular}{|l|l|l|}
\hline Aspects of inquiry & Orchestration events & $\begin{array}{l}\text { Role of Knowledge } \\
\text { Forum (when used) }\end{array}$ \\
\hline \multirow{2}{*}{$\begin{array}{l}\text { EPISTEMIC } \\
\text { PRACTICES }\end{array}$} & Discussing ways of deepening inquiry (f=13) & $\begin{array}{l}\text { Collective basis or } \\
\text { Developing object }\end{array}$ \\
\cline { 2 - 3 } & Discussing ideas (f=20) & Collective basis \\
\hline PRELECTIVE & Recollecting previous inquiry activities (f=15) & \\
\cline { 2 - 2 } & Assessing the advancement of inquiry $(\mathrm{f}=24)$ & \\
\hline \multirow{2}{*}{$\begin{array}{l}\text { PRAGMATIC } \\
\text { PRACTICES }\end{array}$} & Practical guidance of inquiry $(\mathrm{f}=20)$ & Collective basis \\
\cline { 2 - 2 } & Practical management of activity $(\mathrm{f}=31)$ & \\
\hline
\end{tabular}

The teacher maintained the epistemic aspect of inquiry by supporting practices wherein the students discussed ideas as well as ways of deepening inquiry. In discussing ways of deepening inquiry events, the class was engaged in the collective development of strategies to continue the inquiry at hand. When the class was collectively discussing ideas, they addressed the concrete content or phenomenon targeted by their inquiry (i.e., object of collective inquiry). Both events focused on understanding the phenomenon and advancing the epistemic artifacts under construction. 
Teacher's longterm orchestration of collaborative inquiry

The level of reflection necessary to advance inquiry was maintained through orchestration events related to recollecting previous inquiry activities or assessing the advancement of an inquiry (see Appendix 1). By recollecting previous inquiry activities, the teacher aimed at activating the students' memories of previous activities (e.g., information from a mind map and museum visits) on which the subsequent inquiry was built. During the assessment of the advancement of an inquiry, she gathered the class to reflect on the present situation and how they should proceed. These reflective practices were needed to bridge past and future inquiries in the present and enable advancement by changing or redirecting inquiries as necessary.

Furthermore, the teacher maintained the pragmatic aspects of the work by providing practical guidance and/or managing the activity (see Appendix 1). During the practical guidance of inquiry events, she concentrated on providing practical guidance for advancing the inquiry. Occasionally, the guidelines involved detailed explanations of how to speak in turn, what to observe, how to write notes, how to take care of responsibilities or distribute the work, and how to adequately participate in inquiry. During the practical management of activity, the teacher focused on organizing the physical arrangements for working. She organized the classroom space according to the requirements of the activity and provided instructions or permission to start or stop, thus handling the lesson transmission. The pragmatic components of the work included building and managing social relations and interactions, as well as handling and enabling an effective inquiry process.

KF played a distinct role in each type of inquiry practice, although its usage was not always foregrounded. The epistemic practices involved placing students' ideas at the center of joint activity during whole-class episodes. The ideas represented by KF sometimes provided the basis for referring to or discussing the phase or advancement of the project (see Figure 2a). At other times, KF entailed developing the object of inquiry while the epistemic ideas were projected on the shared screen and collectively developed further (see Figure $2 \mathrm{~b}$ ). When used in the context of reflective practices, KF functioned only as a collective basis for inquiry. Students' ideas were often gathered by the teacher and collectively examined using the shared screen. At times, an individual student's notes inspired discussion and helped the class find ways of 
Teacher's longterm orchestration of collaborative inquiry

continuing. When used in a pragmatic context to represent the students' ongoing inquiry, KF functioned as a collective basis for their activity. To prepare their forthcoming activities, the teacher sometimes created new views that shaped the pragmatic activities.
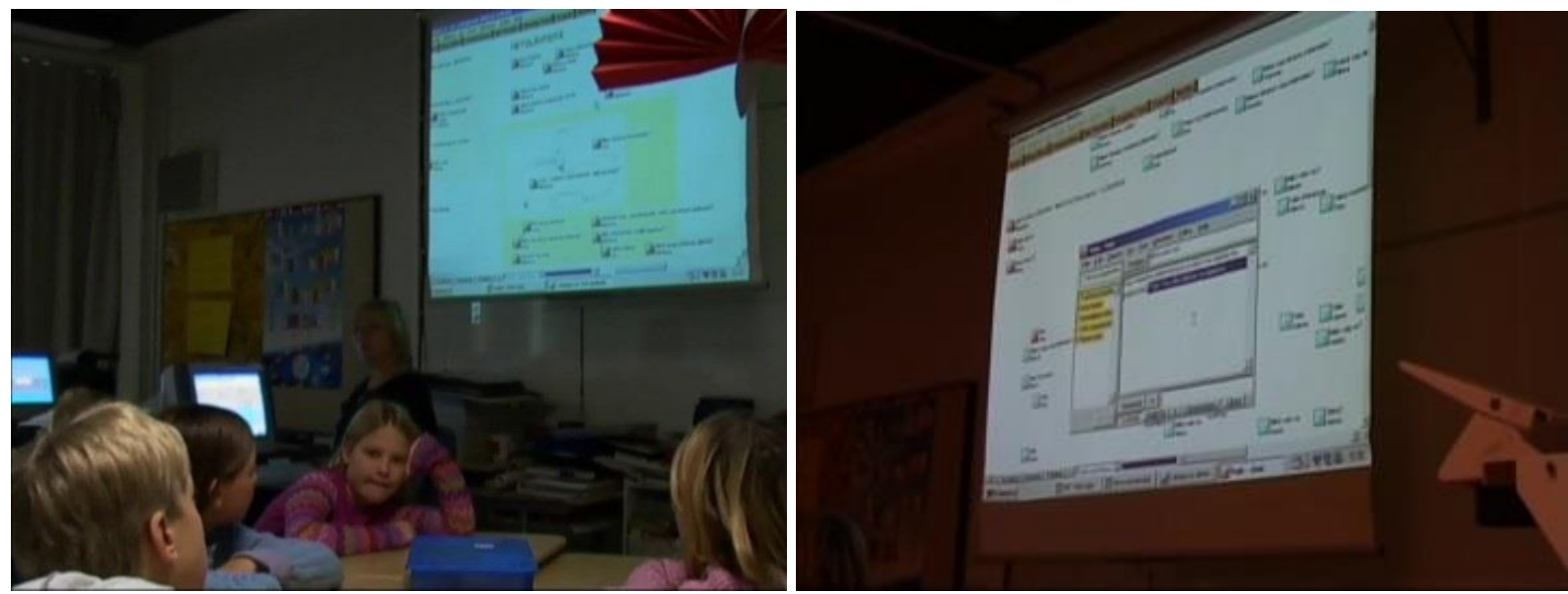

(Insert Figures 2a and 2b about here, e.g., next to each other.)

Figure 2a. KF as a collective basis. The teacher capitalized on the students' KF notes to deepen their inquiry. Their discussion on the interior of a cable was based on the students' earlier experiments.

Figure $2 b$. KF as a developing object. The class collectively read through and organized their initial working theories and questions on the basis of the main question: What is light, and how does the lamp produce its light?

In the following analysis, we used the CORTDRA diagrams to examine how the longitudinal inquiry process was facilitated by various orchestration events and how KF was used during the whole-class episodes. The CORDTRA diagrams (Figures 3a and 3b) visually represent the development of the longitudinal artifact project. The diagrams allowed us to trace and visually depict unfolding interrelations among recorded inquiry episodes, orchestration events, and the use of KF (Klette, 2009). The vertical axis represents the categories defining the same units of analysis - the nature of orchestration events and the use of KF. The horizontal axis refers to the timeline of the project phases (Past phase in Figure 3a and Present phase in Figure 3b) associated with the whole-class episodes and the flow of orchestration events within the 
Teacher's longterm orchestration of collaborative inquiry

episodes. The red vertical lines mark the time periods (days or weeks) during which we were absent from the classroom. The black vertical lines signify other breaks between episodes due to a change in the aim of an activity or a lesson break. The vertical rectangles denote the teamwork episodes in which the students continued their project activities between or after the whole-class episodes.
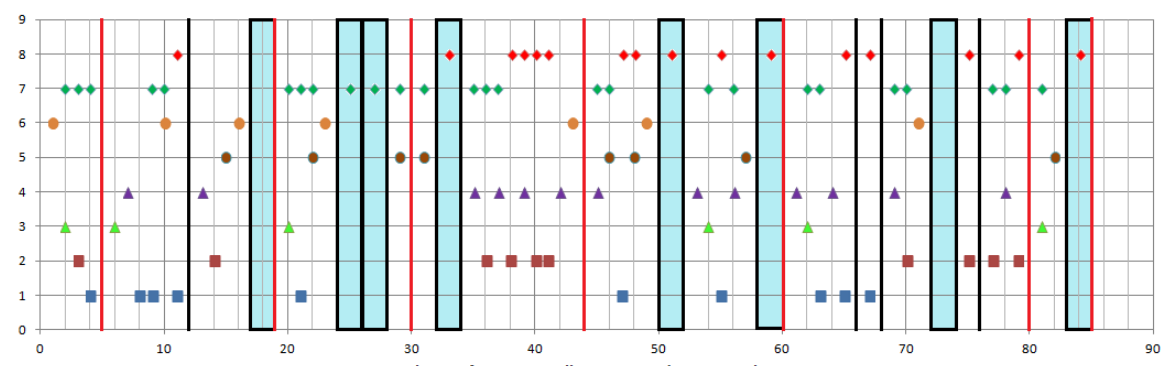

४ 8 Role of KF, Developing object

$\rightarrow 7$ Role of KF, Collective basis

- 6 Practical management of activity

- 5 Practical guidance of inquiry

$\triangle 4$ Assessing the advancement of inquiry

$\triangle 3$ Recollecting previous inquiry activities

- 2 Discussing deepening inquiry

1 Discussing content

Chains of events in collective episodes in Past phase

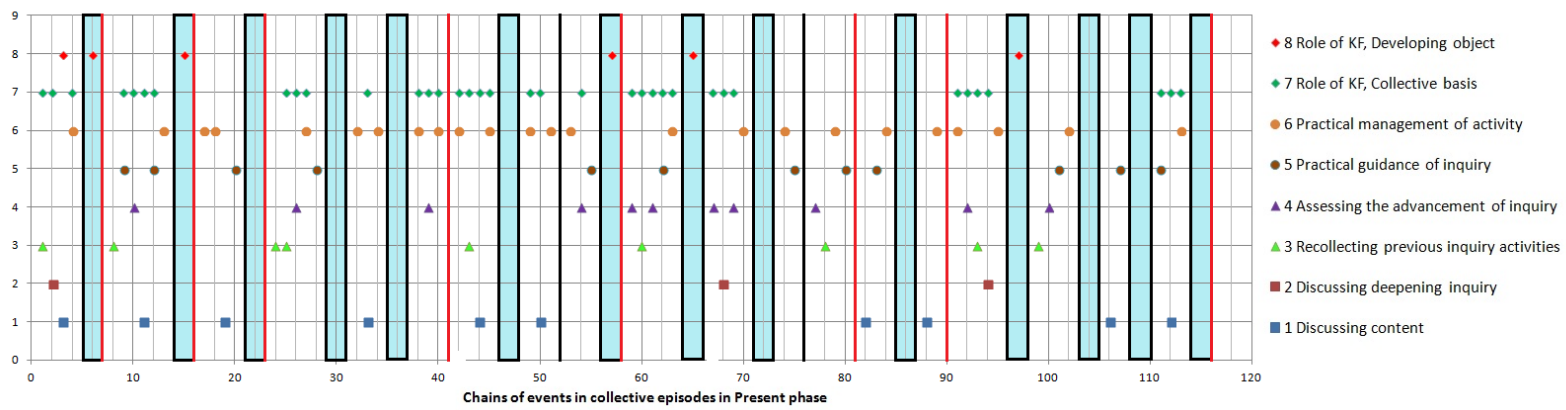

Figure 3a. Past phase. Figure 3b. Present phase. The CORDTRA diagrams of interrelations among recorded inquiry episodes, orchestration events, and use of $\mathrm{KF}$.

Analysis of the CORDTRA diagrams revealed the regular presence of orchestration events throughout the project. Despite the varied order of different orchestration events during the episodes, we interpreted the unfolding pattern of the events maintained by the teacher. The beginning event or one of the events beginning the episode was reflective; the teacher engaged her students in recollecting previous inquiry activities or assessing the advancement of an inquiry (where we are now and where we need to go) (marked with a green or violet triangle in Figures $3 \mathrm{a}$ and $3 \mathrm{~b}$ ). The epistemic events wherein the students and the teacher were discussing ideas or 
Teacher's longterm orchestration of collaborative inquiry

discussing how to deepen the inquiry (what we know and understand and how to study more) occurred often in the middle of the episode following the reflective event. The episodes generally ended with pragmatic events involving the teacher's practical guidance and/or management of the activity before moving to teamwork (how to organize a subsequent activity). However, some episodes did not comprise all types of mediated practices; for example, the epistemic practices were not always present. Usually, such whole-class episode happened before or after a teamwork activity during which the students continued their inquiry process.

The analysis also revealed certain differences between the Past and Present phases of the project regarding the pattern of the orchestration events. There appeared to be more events that involved reviewing the advancement of the inquiry and discussing the deepening of the inquiry in the Past than in the Present phase. This is understandable because more planning and practicing of an inquiry were needed when starting the project. In the Present phase, the collective activities concentrated on experimenting with light and electricity. Hence, shorter chains of events occurred around the pragmatic organization than in the Past phase.

The CORDTRA diagrams further revealed that KF was actively used during both of these phases of The Artifact Project and mostly used as collective basis for working. In providing guidance for the students' teamwork, the role of KF as an epistemic instrument of the developing object was more central in the Past than in the Present phase. However, during the Present phase, the KF database was mostly developed through students' teamwork instead of through wholeclass activities.

Sawyer $(2004,2011)$ emphasizes that the pursuit of emergent processes needed for the collaborative creation of knowledge requires many shared epistemic routines or recurring patterns of activities that dynamically structure the emergent aspects of creative processes. While the orchestration events provided routines for the participants to rely on and to anticipate the ongoing situation, these events also offered the chance to collectively deal with unforeseen challenges and novel opportunities. Although the present inquiry project was longitudinal, the nature of reflective, epistemic, and pragmatic events was relatively stable across the project. The data did not indicate a change in the teacher's orchestration practices during the project, for instance, as a function of the participants' familiarity with the practices. The nature of 
Teacher's longterm orchestration of collaborative inquiry

orchestration events was sometimes more flexible and at other times, more structured (see also Klette, 2009; Lehesvuori et al., 2013); however, their main aim within the activities did not change. In the following section, we provide a more detailed, contextual description of orchestration events by describing their interrelation within a particular episode and linking this episode to the longitudinal trajectory from the teacher's perspective, using data from her diary.

\section{Flow of orchestration events during whole-class episodes}

Here, we use one example to depict how the flow of orchestration events formed a collective episode, illustrating the teacher's orchestration efforts during the long-term inquiry process. The example was selected for describing part of the longitudinal trajectory, during which mutual knowledge advancement progressed through changes between whole-class activities and team activities. This cumulative process was collated through KF. To demonstrate this, we selected a whole-class episode that provides a meaningful and holistic narrative and reveals: (a) How the various types of orchestration events assisted in advancing the collective episode; (b) The teacher's strategic reflections and the background information about the activities through her reflective diary; (c) How the episode and the teacher's reflections were part of the trajectory (continuum) in pursuing the longitudinal, object-oriented inquiry; (d) How KF maintained the object-oriented inquiry trajectory.

Based on these criteria, we present Episode 26 in detail from the beginning of the second (the Present) phase of the project. In the Present phase, the collective episodes were based on experimentation with the physical phenomena of the artifacts that continued and deepened the questions that were already set in the Past phase. The teacher decided that the entire class would concentrate on these phenomena by creating problem frames within teams. In the Past phase, one team researched the historical development of lamps, their functions, and the effects of lamp designs. In the past phase, each team's inquiry processes and research questions were organized in separate KF views. At the beginning of the Present phase, all of the students first created their own initial theories of what light is and how a lamp produces light in the new KF view (named Lamp and related phenomena) that the teacher created. 
Teacher's longterm orchestration of collaborative inquiry

The teacher's background organization of the work in KF is reflected in her diary. We interpreted that the teacher was not satisfied with the students' initial theories in KF view:

"I decided to do a new view [in KF] named 'lamp and related phenomena' for the purpose [i.e., producing specific theories and questions for answering the main question]. Theories were written. I read the theories. I was thinking that they should somehow be organized, because the view seemed to be rather chaotic. The theories were still quite superficial. /.../ However, I was glad when I noticed how some issues from the history phase [Past phase] were brought up now."

Next, before the example episode, the teacher and the students together evaluated this collective KF view. The students similarly pointed out that this KF view needed organizing (see also Viilo, Seitamaa-Hakkarainen, \& Hakkarainen, 2016). Thus, together, they created a plan to organize the theories under collectively invented headings; each team then continued with the organization of the KF view. Later, the teacher recorded the questions generated by the students, which emerged through interactions with her:

"30.9. We were examining what kind of $[\mathrm{KF}]$ notes had been made. We were organizing notes under the headings that we had created together. At the same time, we were considering what kinds of questions the notes were answering: Where does the light come from? What is producing the light? The source of light. What is light? How can the light be used? What is light like? Burning."

However, her later reflections in the diary indicated her continued dissatisfaction with the progress of the students' theories. The teacher collated the organized students' theories in the same view and placed them on the shared screen at the beginning of Episode 26. The activities in our example (Episode 26) showed how the teacher wanted her students to continue the questionexplanation process and tried to invite students to develop their own theories in KF. The episode demonstrates the teacher's response to the students' current thinking and work on KF. She began by discussing her own ideas with the students and referred to their past activities, while switching off the lights in the classroom, to organize the class for the episode and recollect previous inquiry activities. Her main concerns are presented in the following extract from this event:

.../What if we first look at what we've accomplished. I think we need to start from there. In my opinion, you didn't go into enough detail about the light thing. But I'll make that [text on the screen] a bit bigger. /... [Recollecting previous inquiry activities] 
Teacher's longterm orchestration of collaborative inquiry

Guiding the students to concentrate, the teacher led them to assess the ongoing phase of the project and to consider those issues that were not present in their initial theories. The teacher provided practical guidance for reading the shared screen quietly:

\footnotetext{
"Now I hope that you won't talk at all yet, but instead look, so this would awaken some ideas. Hey, put the pencils away. So I've now collected all of them into one pile. Quietly read by yourself, then soon I'll scroll down. Quietly by yourself without useless chatter. Think about what is essential about the light (long break). [Practical guidance for inquiry]
}

The next reflective event, assessing the advancement of inquiry, proceeded in silence while the teacher asked the students to reflect on their KF notes and ponder the need for further "why" questions:

"Then you still have these questions in your notes at the end (break, where they read and reflect quietly). Now I hope that you've come up with some "why" questions about the light. Things that weren't answered by your theories. Does anyone have any "why" questions"

[Assessing the advancement of inquiry]

The silent assessment and review served as a basis for the present ideas to be developed in the next epistemic event, discussing ideas, when the teacher urged the students to think about the important characteristics of light. Here, she directed the students' attention to their written theories in the KF notes. However, she selected only a few students' answers to be shared collectively and did not focus on maintaining the discussion. She seemed to have a plan, and her aim was to direct the students' attention to the content of their notes:

\footnotetext{
"Teacher: What do you think is essential about light? Just the most important things. Michael: You cannot touch or feel it in any way, except through sight.

Teacher: That's good. Let's start from there; we sense light through sight. So what do we see when we sense light? Many of you have listed light sources in your work; well, what light sources are there? Anna: (unclear) Lamp.

Teacher: So this kind of light sources that produce the light themselves. A candle is a good example. Well, what is it that produces light in this world? Nico?

Nico: The sun.

Teacher: But we also see things other than the light sources. We see many things that don't create light. Now think of "why" questions that relate to this. Does anything come to mind?" [Discussing ideas]
}

This discussion suggested the teacher's desire to direct the students' attention to the epistemic work and no longer engage in the collective development of the theories. Next, as part of practical inquiry guidance, guidelines were given on how the students should continue. Here, 
Teacher's longterm orchestration of collaborative inquiry

the teacher encouraged her students to develop their own theories, re-evaluate their ideas, and continue with further questions:

"Now think of the kind of "why" questions that relate to this. Does anyone have any? Do you think you could continue from your own theories by adding "why" questions to them? Because then the nature of light would become clearer to you as you're talking about the essence of light. If we try it like that, then we can't all work at the computers this morning. And then you should look up your own theory [in KF] and continue there with further questions." [Practical guidance for inquiry]

She concluded this whole-class episode with practical management of the activity. Here, she created the physical arrangements for working and guided the students to work in pairs, using the computer:

"(unclear)

Teacher: You could do it like that in pairs, but now it's more important that it contains the "why" questions. Who already has an idea of some "why" questions? Now, since we can't all fit in here, you go first (lists students names). Do you have any ideas, Dan?

Let's continue then; we have our final class in the computer lab.

Theo: Hey, teacher, there's a typo in the first paragraph.

Teacher: Would someone join Laura?

Teacher: And the rest of us will continue with this math.

[Practical management of activity]

The reflections in her diary indicated that she had not been satisfied with the progress of the project thus far, but she urged and helped the students to concentrate and deepen their thinking. After the reiteration of this why-question-explanation process in KF, she gave the student teams the freedom to independently choose their research topics. Later, in her reflective diary entry, she noted her relief that the students were able to come up with relevant questions in the KF notes without too much direction from her. Subsequently, the aim was to plan the study of their chosen topics and form core questions about them:

"2.10. I urged them to wonder and make more in-depth why questions. I remember explaining that the theories were not yet detailed and deep enough. /.../

Now we were getting deeper into things. The questions started to become more detailed and focus on some specific phenomena related to light. In fact, we discovered many varied things about light, and the groups themselves chose a topic that they wanted to start to study.

I asked the students to think about how light could be studied. They wrote about this in their notes, which contained their core questions. Later, I asked the students to make a proper research plan and to explain what tools and equipment they would need. /.../

The groups later went through the questions thoughtfully, also reading the other groups' questions. Each group then tried to choose or modify the core question [that] they would be studying. The students did this 
Teacher's longterm orchestration of collaborative inquiry

in groups, sitting at tables; one of them wrote their core question in KF. In addition, the students wrote combined notes on how they could study light."

As shown in the teacher's diary entries before Episode 26, she was delighted by how the students' own theories written in KF notes were building on their knowledge from the Past phase. The teacher's diary entries subsequently revealed the students' ability to continue their inquiry process beyond the described episode. This was due to the teacher's active background work (i.e., she had followed the students' achievements in KF before the session) and practical guidance during the whole-class episode. When examining the students' research questions and theories in KF together, the teacher's instructional ideas supported their deepening inquiry. The teacher's reflections after the episode also represented the continuum of the process afterwards; the student teams set the final questions that they wanted to study in KF. Teacher guidance was also crucial to organizing peer support for modifying the questions in KF. According to the teacher's reflective diaries, she later guided the students to design science experiments based on these questions in order to develop explanations. Throughout, the role of KF was crucial in supporting the process trajectory; it mediated the cumulative nature of the inquiry and connected the teacher's and the students' mutual efforts.

In the episode example, KF was used as a collective basis for the project. The students' ideas recorded in KF notes were projected on the shared screen. If used, KF generally worked as a collective basis for all reflective events. In the episode example, the reflection occurred when earlier student questions were projected on the wall using KF; the students' role in this event involved silent reading. This way, the teacher encouraged them to consider the need for more explanation-seeking questions. Similarly, the KF notes that students had generated earlier were often projected on the wall during the epistemic events. These prior ideas were often used as a basis for developing the content of the inquiry. However, sometimes the KF ideas were developed collaboratively, and KF worked at the same time as a developing object that mediated the process (Viilo et al., in press). Nevertheless, in this episode example, the epistemic event was the teacher's brief interaction with the students: the event focused the students' attention on the object of their inquiry. Later, in episode 27, students continued working with KF to deepen their inquiry process further. Overall, during the pragmatic guidance and organization events, KF 
Teacher's longterm orchestration of collaborative inquiry

always worked as the collective basis for the project if used. As in the cited episode, the teacher often referred to the process in $\mathrm{KF}$ and practically organized further student work, but $\mathrm{KF}$ remained in the background.

While the present investigative project involved the pursuit of genuine inquiry with emergent problems and directions, it was not open-ended in terms of allowing the spontaneous and free production of ideas. The project included learning objectives to understand the functions of cultural artifacts at multiple levels. These objectives guided the teacher's efforts to orchestrate collective inquiry activities. Had the teacher not recognized promising paths in the students' classroom work and KF notes, the students would likely have only scratched the surface of the phenomena.

\section{Discussion}

This study examined how an experienced elementary teacher orchestrated the collaborative inquiry process across a long-term project on artifacts. The participating students collectively built and shared their knowledge by using KF, an advanced, collaborative software application. The results of the present case study highlighted how the teacher was able to orchestrate The Artifact Project in a contingent manner while responding to the ideas and interests that students developed during the process (Sharples \& Anastopoulou, 2012; Sawyer, 2011). Her orchestration design aimed at developing the collective emerging process (Sawyer, 2011; Zhang et al., 2011), not at completing pre-set inquiry procedures (Kirschner, Schweller, \& Clark, 2006). Nevertheless, she continuously reflected on the ongoing process and guided students to follow certain rules and standards, such as establishing productive research questions and making plans of inquiry (Beghetto \& Kaufman, 2012; Cazden, 2001; Jurow \& Creighton McFadden, 2011; Olson, 2007). The realized orchestration often relied on KF, which promoted the collective recollection of past processes and inquiry outcomes. This, in turn, supported joint reflections on how to advance and focus subsequent inquiry efforts. In short, the orchestration during the enacted activities included specific objectives, while providing opportunities for mutual, as well as unexpected, development (Sawyer, 2011; Sharples \& Anastopoulou, 2012). 


\section{Teacher's longterm orchestration of collaborative inquiry}

The results indicated that the teacher maintained the inquiry during the whole-class episodes through six types of orchestration events, which fell under epistemic, reflective, and sociopragmatic categories. These were routines and patterns of inquiry that facilitated the coordinated pursuit of inquiry efforts across extended time frames. The categories were defined in terms of the mediation modes distinguished by Beguin and Rabardel (2000; see also Ritella \& Hakkarainen, 2012). The CORDTRA analysis revealed that the aspects of inquiry were relatively stable across the longitudinal inquiry project, and the teacher's orchestration practices were likewise consistent throughout. Using the orchestration events, the teacher interlinked the different lines of inquiry and results of the ongoing discussions.

The results suggest that it is critical to engage students in work with conceptual artifacts and improvement of their ideas, but such epistemic mediation is not enough. It is equally important to create reflective practices that occasionally involve gathering students to jointly reflect on their current level of knowledge and plan the advancement of subsequent inquiries (Bybee, 2000; Roth, 1998). Moreover, ideas do not become activities without deliberate social organizing, which involves solving the emerging pragmatic problems of cognitive labor distribution, activity coordination, and integration of diverse inquiry lines (Hakkarainen, 2009). In this study, the teacher facilitated the reflective assessment of an inquiry, as well as established corresponding classroom practices; this was essential to the subsequent building and creating of knowledge in small groups.

Recent research has explored the relationship of dynamic orchestration and improvisational teaching (Sawyer, 2004; Sharples \& Anastopoulou, 2012). The pursuit of emergent processes requires several shared epistemic routines that dynamically structure the evolving aspects of creative processes (Sawyer, 2004, 2011). In this study, the teacher's epistemic, reflective, social, and pragmatic knowledge work provided routines for the participants. In improvisational and emergent interactions, the members try to build on each other's turns and operate in a changing environment (Sawyer, 2009). In this study, the disciplined improvisation (Sawyer, 2004) was not interpreted as momentary spontaneity, but as the longitudinal emergence of the project that provided opportunities for the unexpected (see also 
Teacher's longterm orchestration of collaborative inquiry

Beghetto \& Kaufman, 2012). From this perspective, we were able to observe how the participants built on each other's contributions by advancing the collective objective of inquiry during whole-class episodes. The knowledge work performed in teams and collective classroom episodes were embedded in the long-standing trajectories of building on the students' ideas and inquiries.

During the whole-class episodes, the processes and outcomes of inquiry mediated by KF were often projected on the wall to be discussed, referred to, or developed. KF enabled externalizing, that is, it made the inquiry process visible, activated previously created knowledge, and brought it to the center of attention (Scardamalia, 2002). KF also connected the process across several dimensions, including student authority and teacher structuring and background organization. Its usage was integrated with inquiry practices enacted by the participants, becoming a "routine" or embedded practice within the classroom.

Essentially, the main challenge in orchestrating inquiry-based learning is managing the balance of control between teachers, students, and technology and allowing learners the freedom to explore within a structure that guides their process (Sharples \& Anastopoulou, 2012). Serious inquiries are object-oriented rather than open-ended in nature and this affects the nature of teacher guidance as well. In this project, we demonstrated how teacher orchestrations were oriented toward guiding the class to pursue the project's objectives.

Thus, the implementation of longitudinal, collaborative inquiry learning requires teacher support at multiple levels. An emerging project demands a flexible framework (macro level), considering the high-level conjecture on how to support learning (Sandoval, 2014). Such a project includes various pedagogical properties, such as the object of inquiry, a long time frame (month or school term), participant structures (i.e., whole class and teamwork), various learning activities (e.g., designing science experiments and making prototypes), visits to museums, and use of technology and tools (Roth, 1998). Furthermore, the longitudinal orchestration should be based on appropriating, adapting, and modifying learning activities such that students' ideas can be utilized. Such a project requires background work between sessions to create conditions for the advancement of the inquiry (meso level). Additionally, during the enacted learning activities, 
Teacher's longterm orchestration of collaborative inquiry

the teacher's orchestration should be based on the unique contributions that the students bring to the curriculum (Roth, 2002; Sawyer, 2004; Zhang et al., 2011). The teacher's orchestration actions should be responsive and adjusted to support the targeted inquiry (micro level) (Parker \& Borko, 2012; Sawyer, 2012).

\section{Limitations and implications}

This case study only provides a tentative suggestion of how inquiry learning can be implemented and promoted in elementary education. Because a case study occurs in complex real-world settings, many variables cannot be controlled (Yin, 1994). Due to the qualitative nature of the analyses, this research does not prove that the present inquiry approach could always be successfully applied in different environments. Teaching and learning are always performed in contextual settings and tend to be local in nature (Hedegaard \& Chaiklin, 1995). However, only experiences with context-dependent research settings can develop our understanding and expertise in organizing and scaling up inquiry learning (Bielaczyc, 2013; Flyvbjerg, 2006). Thus, there is a need for research on how to organize classroom practices around authentic inquiry processes that integrate various school subjects and support students' collaboration (Chinn \& Malhotra, 2002; Scardamalia, 2002).

We conducted an in-depth analysis of video-recorded whole-class episodes that demonstrated the teacher's guidance practices. Data analysis methods were created in accordance with theory- and data-driven qualitative content analysis and were conducted systematically. For practical reasons, we were unable to record all the episodes of the project; however, the teacher's diary was used to confirm the representativeness of the video data. Between the whole-class episodes, the students always worked in teams. These small group episodes were excluded from the analysis, because we focused on the teacher's longitudinal orchestration. Overall, the data provided a comprehensive picture of the teacher's guidance (Cohen, Manion, \& Morrison, 2007).

Whole class teaching is a central school practice (Alexander, 2004; Myhill, 2006). In the present case, the aim was to analyze the teacher's longitudinal orchestration: how the teacher guided students and discussed ongoing ideas or content during whole class teaching. However, whole class teaching is often constructed primarily around the teacher's agenda (Myhill, 2006). 
Teacher's longterm orchestration of collaborative inquiry

Although the whole-class episodes were inherent to the longitudinal Artifact process, the video data collected from them can only show a part of the overall collective practices. In the present case, the teacher's diaries depict how the whole-class episodes were based on the students' previous work and how the teacher built on these ideas. On the other hand, one limitation of our study is that we did not analyze how the teachers' speech or discourse patterns shaped the learning situations (Klette, 2009; Lehesvuori, \& al., 2013; Myhill, 2006). More rigorous analysis is required to reveal how the interaction built on or hindered the different phases of the longitudinal inquiry.

As the CORDTRA analysis showed (Figure 1 and 2, see also Appendix 1), the analyzed episodes did not always include all types of mediated practices or events. The primary purpose for selecting the example episode was to illustrate the flow of various orchestration events within the same episode. However, in selecting the episode, we also wanted to offer a meaningful and holistic narrative that would characterize the teacher's orchestration work from several perspectives. The aim was to describe one part of the longitudinal trajectory during which mutual knowledge progressed alternately through activities in groups and with the whole class and KF collated the cumulative process (see the detailed selection criteria in the subsection entitled Flow of orchestration events during whole-class episodes). In addition, the selected episode illustrated the role of KF, which was crucial in highlighting students' ideas, whether or not the event itself was interactive. Although these phenomena were present in different combinations throughout the project, our objective to find an episode that illustrated several aims limited the possibilities to only a few episodes.

Furthermore, this study adopted new methods of analyzing the temporal trajectory of orchestration events. We applied CORDTRA diagrams that supported chronological analysis. Since this was the first attempt to use the CORDTRA method in the context of teacher orchestration, the unit of analysis was an event, not a verbal statement, as in previous studies that analyzed video data (e.g., Hmelo-Silver, 2003; Puntambekar, Stylianou, \& Goldstein, 2007). This approach allowed us to visualize the trajectories of all the events during the project. As highlighted by Lemke (2000), students participate in learning processes in multiple timescales. 
Teacher's longterm orchestration of collaborative inquiry

Lemke explains that we have limited knowledge of the teacher's guidance in cumulative, collaborative learning processes that are sustained over longer periods of time. In this study, the use of the data visualization technique conveyed a dynamic sense of time and the transition between orchestration events used during the defined periods (see also Lehesvuori et al., 2013). Additionally, although video data were not always available from all of the project activities, we were able to examine the teacher's orchestration through different timescales - during the different episodes and project phases. Similar analyses will open new possibilities for other multiple timescale studies.

As Klette (2009) and Lehesvuori and colleagues (2013) suggested, it would be valuable to consider multiple levels of analysis in order to establish complementary and reliable interpretations. Visualization of multiple coding categories and how these construct different trajectories as well as support of the cumulativeness of learning are still quite rare (Lehesvuori et al., 2013; Lemke, 2009). Graphical representations of these trajectories provide valuable material for both research and teacher education (Lehesvuori et al., 2013) by elucidating the implementations of pedagogical aims. The present study is one of these rare contributions. Moreover, it might be fruitful to compare visualized lesson plans (Dillenbourg, 2015) with graphs of executed lessons to gain a better understanding of how lesson plans are realized in classroom interactions.

In conclusion, to expand and scale up advanced inquiry practices, teachers' actual work in designing and conducting longitudinal inquiry projects should be made visible and analyzed in detail. Despite their considerable pedagogical value, such projects are uncommon and difficult to implement because of the constraints in subject-based curricula. To a significant extent, this project relied on the high degree of teacher autonomy that characterizes the Finnish education system (Haargreaves \& Shirley, 2009). Moreover, the National Core Curriculum for Basic Education highly values teachers' pedagogical knowledge and skills and provides them the flexibility to implement subject content and design in their own local curricula (Sahlberg, 2011). This strategy creates opportunities for teachers to conduct integrative projects that combine several school subjects. Analysis of teachers' long-term orchestrating practices improves our 
Teacher's longterm orchestration of collaborative inquiry

potential to offer pedagogical models for inquiry projects and overcome the limitations of traditional school culture (Bielaczyc, 2013).

\section{References}

Alexander, R. J. (2004) Towards dialogic teaching: rethinking classroom talk. York: Dialogos. Angelillo, C., Rogoff, B., \& Chavajay, P. (2007). Examining shared endeavors by abstracting video coding schemes. In R. Goldman, R. Pea, B. Barron \& S. J. Denny (Eds.), Video research in the learning sciences (pp. 189-206). Mahwah, N.J: Lawrence Erlbaum Associates, Inc.

Ash, D. (2007). Using video data to capture discontinuous science meaning making in nonschool setting. In R. Goldman, R. Pea, B. Barron \& S. J. Denny (Eds.), Video research in the learning sciences (pp. 207-226). Mahwah, N.J: Lawrence Erlbaum Associates, Inc.

Barker, L., \& Borko, H. (2011). Conclusion: Presence and the art of improvisational teaching. In R. K. Sawyer (Ed.), Structure and improvisation in creative teaching (pp. 279-298). New York: Cambridge University Press.

Barlex, D. (2007) Assessing Capability in Design and Technology: The case for a minimally invasive approach. Design and Technology Education: an International Journal, 12(2):49-56.

Beghetto, R., \& Kaufman, J. (2011). Teaching for creativity with disciplined improvisation. In R. K. Sawyer (Ed.), Structure and improvisation in creative teaching (pp. 94-111). New York: Cambridge University Press.

Béguin, P., \& Rabardel, P. (2000). Designing for instrument-mediated activity. Scandinavian Journal of Information Systems, 12, 173-190.

Bielaczyc, K. (2006). Designing social infrastructure: Critical issues in creating learning environments with technology. Journal of the Learning Sciences, 15(3), 301-329. doi:10.1207/s15327809jls1503_1 
Teacher's longterm orchestration of collaborative inquiry

Bielaczyc, K. (2013). Informing design research: Learning from teachers' designs of social infrastructure. Journal of the Learning Sciences, 22(2), 258-311.

doi:10.1080/10508406.2012.691925

Bybee, R. W. (2000). Teaching science as inquiry. In Inquiring into Inquiry Learning and Teaching in Science, J. Minstrell and E. H. v. Zee, eds. Washington, DC: American Association for the Advancement of Science.

Cazden, C. B. (2001). The classroom discourse - The language of teaching and learning. Heinemann: Portsmouth.

Chan, C. (2011). Bridging research and practice: Implementing and sustaining knowledge building in hong kong classrooms. International Journal of Computer-Supported Collaborative Learning, 6(2), 147-186. doi:10.1007/s11412-011-9121-0

Chi, M. T. H. (1997). Quantifying qualitative analyses of verbal data: A practical guide. Journal of the Learning Sciences, 6(3), 271-315. doi:10.1207/s15327809j1s0603_1

Cohen, L., Manion, L., \& Morrison, K. (2007). Research methods in education (6th ed.). New York: Routledge.

Derry, S.J., Pea, R.D., Barron, B., Engle, R.A., Erickson, F., Goldman, R., Hall, R., Koschmann, T., Lemke, J.L., Sherin, M.G. and Sherin, B.L. (2010). Conducting video research in the learning sciences: guidance on selection, analysis, technology, and ethics. Journal of the Learning Sciences, 19(1), 3-53.

Dillenbourg, P. \& Jermann, P. (2007). Designing integrative scripts. In F. Fischer, I. Kollar, H. Mandl \& J. M. Haake (Eds.), Scripting computer-supported collaborative learning: Cognitive, computational, and educational perspectives (pp. 275-301). New York: Springer.

Dillenbourg, P., Järvelä, S., \& Fischer, F. (2009). The evolution of research on computersupported collaborative learning: From design to orchestration. In N. Balacheff, S. Ludvigsen, T. de Jong, A. Lazonder \& S. Barnes (Eds.), Technology-enhanced learning. principles and products (pp. 3-19). Dordrecht: Springer. 
Teacher's longterm orchestration of collaborative inquiry

Dillenbourg, P. (2013). Design for classroom orchestration. Computers \& Education, 69, 485492. doi:10.1016/j.compedu.2013.04.013

Dillenbourg, P. (2015). Orchestration Graphs. Modelling scalable education. Lausanne: EPFL Press.

Erickson, F. (2011). Taking advantage of structure to improvise in instruction; examples from elementary school classrooms. In R. K. Sawyer (Ed.), Structure and improvisation in creative teaching (pp. 113-132). New York: Cambridge University Press.

Flyvbjerg, B. (2006). Five misunderstanding about case-study research. In C. Seale., G. Gobo, J.F. Gubrium, \& D. Silverman (Eds.), Qualitative Research Practice. London: Sage.

Fortus, D, Dershimer, R, Krajcik, J, Marx, R \& Mamlok-Naaman, R. (2004). Design-based science and student learning. Journal of Research in Science Teaching, 41(10):10811110.

Friese, S. (2012). Qualitative data analysis with ATLAS.ti. London: SAGE Publications.

Greiffenhagen, C. (2012). Making rounds: The routine work of the teacher during collaborative learning with computers. International Journal of Computer-Supported Collaborative Learning, 7(1), 11-42. doi:10.1007/s11412-011-9134-8

Hakkarainen, K. (2009). A knowledge-practice perspective on technology-mediated learning. International Journal of Computer-Supported Collaborative Learning, 4(2), 213-231. doi:10.1007/s11412-009-9064-X

Hakkarainen, K. (2003). Progressive inquiry in computer-supported biology classroom. Journal of Research in Science Teaching, 40(10), 1072-1088.

Hargreaves, A \& Shirley, D. (2009). The fourth way: The inspiring future for educational change. London: Corvin.

Hedegaard, M., \& Chaiklin, S. (2005). Radical-local teaching and learning. Aarhus, Denmark: Aarhus University Press. 
Teacher's longterm orchestration of collaborative inquiry

Hmelo-Silver, C., Duncan, R. G., \& Chinn, C. A. (2007). Scaffolding and achievement in problem-based and inquiry learning: A response to kirschner, sweller, and clark (2006). Educational Psychologist, 42(2), 99-107. doi:10.1080/00461520701263368

Hmelo-Silver, C., \& Barrows, H. S. (2008). Facilitating collaborative knowledge building. Cognition and Instruction, 26(1), 48-94. doi:10.1080/07370000701798495

Hmelo-Silver, C., Liu, L., \& Jordan, R. (2009). Visual representations of a multidimensional coding scheme for understanding technology-mediated learning about complex natural systems. Research and practice in technology enhanced learning, 4(3), 253-280.

Hmelo-Silver, C. E. (2003). Analyzing collaborative knowledge construction: Multiple methods for integrated understanding. Computers \& Education, 41(4), 397-420. doi:http://dx.doi.org.libproxy.helsinki.fi/10.1016/j.compedu.2003.07.001

Hong, H., \& Sullivan, F. (2009). Towards an idea-centered, principle-based design approach to support learning as knowledge creation. Educational Technology Research \& Development, 57(5), 613-627. doi:10.1007/s11423-009-9122-0

Jurow, A., \& Creighton McFadden, L. (2011). Disciplined improvisation to extend young children's scientific thinking. In Sawyer, K. (Ed.) Structure and improvisation in creative teaching (pp. 236-251), New York: Cambridge University Press.

Kelle, U. (2006). Computer-assisted qualitative data analysis. In C. Seale, G. Gobo, J. Gubrium \& D. Silverman (Eds.), Qualitative research practice (pp. 443-459). London: SAGE Publications.

Klette, K. (2009). Challenges in Strategies for Complexity Reduction in Video Studies. Experiences from the PISA+ Study: A Video Study of Teaching and Learning in Norway. In T. Janik \& T. Seidel (Eds.) The Power of Video Studies in Investigating Teaching and Learning in the Classroom. Munich: Waxmann, 61-82.

Kirschner, P. A., Sweller, J., \& Clark, R. E. (2006). Why minimal guidance during instruction does not work: An analysis of the failure of constructivist, discovery, problem-based, 
Teacher's longterm orchestration of collaborative inquiry

experiential, and inquiry-based teaching. Educational Psychologist, 41(2), 75-86.

doi:10.1207/s15326985ep4102_1

Lehesvuori, S., Viiri, J., Rasku-Puttonen, H., Moate, J., \& Helaakoski, J. (2013). Visualizing communication structures in science classrooms: Tracing cumulativity in teacher-led whole class discussions. Journal of research in science teaching, 50 (8), 912-939.

Lemke, J. (2000). Across the scales of time: Artifacts, activities, and meanings in ecosocial systems. Mind, Culture, and Activity, 7(4), 273-290.

Littleton, K., \& Kerawalla, L. (2012). Trajectories of inquiry learning. In K. Littleton, E. Scanlon \& M. Sharples (Eds.), Orchestrating inquiry learning (pp. 31-47). London: Routledge.

Littleton, K., Scanlon, E., \& Sharples, M. (2012). Editorial introduction: Orchestrating inquiry learning. In K. Littleton, E. Scanlon \& M. Sharples (Eds.), Orchestrating inquiry learning (pp. 1-6). London: Routledge.

Lonchamp, J. (2012). An instrumental perspective on CSCL systems. International Journal of Computer-Supported Collaborative Learning, 7(2), 211-237. doi:10.1007/s11412-0129141-4

Looi, C., \& Song, Y. (2013). Orchestration in a networked classroom: Where the teacher's realtime enactment matters. Computers \& Education, 69(0), 510-513. doi:http://dx.doi.org.libproxy.helsinki.fi/10.1016/j.compedu.2013.04.005

Luckin, R., Plowman, L., Laurillard, D., Stratfold, M., Taylor, J., \& Corbe, S. (2001). Narrative evolution: Learning from students' talk about species variation. International Journal of Artificial Intelligence in Education, 12, 100-123.

Mercer, N. (2008). The seeds of time: Why classroom dialogue needs a temporal analysis. Journal of the Learning Sciences, 17(1), 33-59. doi:10.1080/10508400701793182

Mercer, N., \& Littleton, K. (2007). Dialogue and the development of children's thinking. London: Routledge. 
Teacher's longterm orchestration of collaborative inquiry

Mäkitalo, A., Jakobsson, A., \& Säljö, R. (2009). Learning to reason in the context of socioscientific problems. exploring the demands on students in 'new' classroom activites. In K. Kumpulainen, C. Hmelo-Silver \& M. Cesar (Eds.), Investigating classroom interaction. methodologies in action. (pp. 7-26). Rotterdam: Sense Publishers.

Myhill, D. (2006). Talk, talk, talk: teaching and learning in whole class discourse. Research papers in education, 21(1), 19-41.

National Research Council. (2012). A framework for K-12 science education: Practices, crosscutting concepts, and core ideas. Committee on a Conceptual Framework for New K-12 Science Education Standards. Board on Science Education, Division of Behavioral and Social Sciences and Education. Washington, DC: The National Academies Press.

Olson, D. (2007). The self-ascription of intention: Responsibility, obligation and self-control. Synthese, 159, 297-314.

Puntambekar, S., Stylianou, A., \& Goldstein, J. (2007). Comparing slassroom enactments of an inquiry curriculum: Lessons learned from two teachers. Journal of the learning sciences, 16(1), 81-130.

Rabardel, P., \& Beguin, P (2005). Instrument mediated activity: From subject development to anthropocentric design. Theoretical Issues in Ergonomic Science, 6, 429-461.

Ritella, G., \& Hakkarainen, K. (2012). Instrumental genesis in technology-mediated learning: From double stimulation to expansive knowledge practices. International Journal of Computer-Supported Collaborative Learning, 7(2), 239-258. doi:10.1007/s11412-0129144-1

Roschelle, J., Dimitriadis, Y., \& Hoppe, U. (2013). Classroom orchestration: Synthesis. Computers \& Education, 69(0), 523-526. doi:http://dx.doi.org.libproxy.helsinki.fi/10.1016/j.compedu.2013.04.010

Roth, W.M. (1998). Designing communities. Boston: Kluwer.

Roth, W. M. (2002). Being and becoming in classroom. Westport, CT: Ablex. 
Teacher's longterm orchestration of collaborative inquiry

Sahlberg, P. (2011). The fourth way of Finland. Journal of educational change, 12(2), 173-184.

Saldana, J. (2009). The coding manual for qualitative researchers. Los Angeles, CA: SAGE.

Sandoval, W. (2014). Conjecture mapping: An approach to systematic educational design research. Journal of the Learning Sciences, 23:1, 18-36. doi:10.1080/10508406.2013.778204

Sawyer, R. K. (2009). The science of social emergence. In G. Trajkovski, \& S. G. Collins (Eds.), Agent-based societies: Social and cultural interactions (pp. 1-16). Hershey, PA: Idea Group Inc.

Sawyer, R. K. (2011). What makes good teachers great? the artful balance of structure and improvisation. In R. K. Sawyer (Ed.), Structure and improvisation in creative teaching (pp. 1-24). New York: Cambridge University Press.

Sawyer, R. K. (2004). Creative teaching: Collaborative discussion as disciplined improvisation. Educational Researcher, 33(2), 12-20. doi:10.3102/0013189X033002012

Scardamalia, M. (2002). Collective cognitive responsibility for the advancement of knowledge. In B. Smith (Ed.), Liberal education in a knowledge society (pp. 67-98). Chicago: Open Court.

Scardamalia, M., \& Bereiter, C. (2006). Knowledge building: Theory, pedagogy, and technology. In R. K. Sawyer (Ed.), The Cambridge handbook of the learning sciences (pp. 97-115). Cambridge: Cambridge University Press.

Seale, C. (2006). Quality in qualitative research. In C. Seale, G. Gobo, J.F. Gubrium, \& D. Silverman (Eds.), Qualitative Research Practice. London: Sage.

Seitamaa-Hakkarainen, P., Viilo, M., \& Hakkarainen, K. (2010). Learning by collaborative designing: Technology-enhanced knowledge practices. International Journal of Technology \& Design Education, 20(2), 109-136. doi:10.1007/s10798-008-9066-4 
Teacher's longterm orchestration of collaborative inquiry

Sharples, M., \& Anastopoulou, S. (2012). Designing orchestration for inquiry learning. In K.

Littleton, E. Scanlon \& M. Sharples (Eds.), Orchestrating inquiry learning (pp. 69-85). London: Routledge.

Song, Y., \& Looi, C. (2012). Linking teacher beliefs, practices and student inquiry-based learning in a CSCL environment: A tale of two teachers. International Journal of Computer-Supported Collaborative Learning, 7(1), 129-159. doi:10.1007/s11412-0119133-9

Stahl, G. (2006). Group cognition: Computer support for building collaborative knowledge. Cambridge, MA: MIT Press.

Viilo, M., Seitamaa-Hakkarainen, P., \& Hakkarainen, K. (2011). Supporting the technology-enhanced collaborative inquiry and design project: A teacher's reflections on practices. Teachers and Teaching, 17(1), 51-72. doi:10.1080/13540602.2011.538497

Viilo, M., Seitamaa-Hakkarainen, P., \& Hakkarainen, K. (in press). Balancing structure and flexibility: Teacher's orchestration in collaborative long-term inquiry. In D. Leat (Ed.) Enquiry and project based learning: Students, schools \& society. London: Routledge.

Yin, R. K. (1994). Case study research: Design and methods (2nd ed.). Newbury Park, CA: Sage Publications.

Zhang, J., Hong, H., Scardamalia, M., Teo, C. L., \& Morley, E. A. (2011). Sustaining knowledge building as a principle-based innovation at an elementary school. Journal of the Learning Sciences, 20(2), 262-307. doi:10.1080/10508406.2011.528317 
Teacher's longterm orchestration of collaborative inquiry

\section{Appendix}

Table A1. Extracts from the different types of orchestration events ( $K F=$ Knowledge Forum).

\begin{tabular}{|c|c|c|}
\hline Category and its definition & $\begin{array}{c}\text { Extract from the orchestration event classified in the } \\
\text { category }\end{array}$ & Illustration \\
\hline $\begin{array}{l}\text { Discussing ways of deepening inquiry (epistemic practice) } \\
\text { The purpose was to develop the strategies for continuing } \\
\text { the inquiry at hand. }\end{array}$ & $\begin{array}{l}\text { Extract from Episode } 3 \\
\text { Teacher: Let's think about, regardless of the object, for } \\
\text { example, these, or those or even those in your pocket. } \\
\text { What kind of questions could you present on these } \\
\text { objects if you wanted to find out about them? Imagine } \\
\text { for example if some new item, what kind of questions } \\
\text { would you ask? What about you Ethan? } \\
\text { Ethan: Um ... What it's for? } \\
\text { Teacher: Mmm. Do any other questions come to mind or } \\
\text { did everyone have this one in mind? } \\
\text { Anna: Yea. } \\
\text { Teacher: Consider, what other questions could you ask } \\
\text { about the object. What kind of questions could you get } \\
\text { answers to? Dane? } \\
\text { Dane: What kind of object it is. } \\
\text { Teacher: Mmm. Sam? } \\
\text { Sam: Where does it belong. } \\
\text { Teacher: Nico? } \\
\text { Nico: Where is it from? } \\
\text { Teacher: These are all good questions, do any more come } \\
\text { to mind? Well who would you ask these questions? } \\
\text { Kristina? } \\
\text { Kristina: Whoever made it. } \\
\text { Teacher: Well, what would you ask the creator? Think } \\
\text { about it when you were asking why questions, what kind } \\
\text { of why question could you ask the creator? Ethan? } \\
\text { Ethan: Why did you make this. } \\
\text { Teacher: How about other why questions? Dane? } \\
\text { Dane: Why is it just for us (unclear) } \\
\text { Teahcer: What about you Sara? } \\
\text { Sara: (unclear) } \\
\text { Teacher: These questions would be great to be able to } \\
\text { ask when you have an object your studying. }\end{array}$ & $\begin{array}{l}\text { The pictures in the KF view showing the ladles that were analyzed after } \\
\text { Episode } 3 \text {. }\end{array}$ \\
\hline
\end{tabular}


Teacher's longterm orchestration of collaborative inquiry Table A1. Continued.

Category and its definition

Discussing ideas (epistemic practice) The purpose was to develop the object of their collective inquiry. During these events the teacher sometimes highlighted also the beneficial aspects of the used strategies.

Recollecting previous inquiry activities (reflective practice) The purpose was to recollect the most important aspects from the previous activities that functioned as guidelines or basis for the next phase.
Extract from the orchestration event classified in the category

Extract from Episode 24

Teacher: In the dark you can't see anything. What about in the light. That's the meaning. We can't see without light. We need light to see. [commenting the issue from the KF-note reflected on the shared screen, reading the new issue]: Well this is all well said, light lights the darkness. You can move it from place to place.

[commenting the student note]: Well, that is those lamp businesses. [reading partly and commenting the next businesses. [reading partly and commenting the next
issue from the note]: But light can be ... what does it issue from the note]: But light can be ... What does it depend on or does what determines if a light is bright or
dim? What causes it? What causes it children? Michael, what do you think?

Michael: [unclear] Fire requires oxygen which it then burns and then requires more energy. The less it's in use the dimmer it is.

Ther: Yea but what question does that answer? Now it's so that, we need to think up new questions. Who hasn't said anything yet? Everybody with raised hands

hasn't said anything yet? Everybody with
has already said something. Tom?

Tom: Well, it answers the question that what a lamp needs to be.

Teacher: Well, now we need to do so that, l'm going to put a new subject here [write down in the KF], so what kind of light there is. Good. There

Extract from Episode 22 Teacher: ... But now let's go back and look at something else. III look at your work, let's look at yours ... have you written more, Ester? I'm sure you have. Let's look at your group, it was the lock and key group. And we put it slightly lower, away from the previous things. Over here the lock and key has started. And then over here is a path that leads to the iron age and is very good that this path is split. There Erica speaks about keys during the iron age and Tom adds about locks. So Tom has rightfully continued the same line of thought adding his own notes...

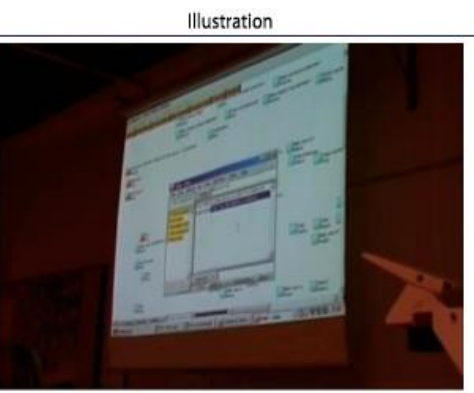

A note to be organized during the event.

(n)

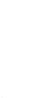

The
The
th
th
the
The

The Lock and Key view from KF that the teacher is using in order to guide students to continue knowledge building.

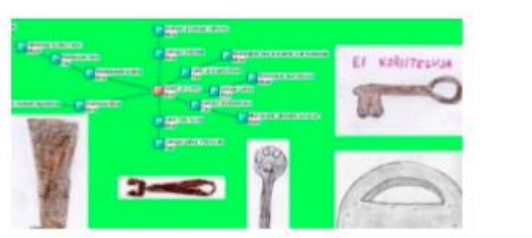


Teacher's longterm orchestration of collaborative inquiry

Assessing the advancement of inquiry (reflective practice) The aim was to do public reflection of present ongoing situation. These events often orientated the situation towards what should be done next.

Practical guidance of inquiry

The teacher concentrated on practical guidelines how to continue. At times, the guidelines were detailed explanations how to speak in turn, what to observe, how to write notes, how to take care of responsibilities or divide the work, and how to behave.
Extract from Episode 30

that you have found actual things, nice things about the lamp and light that we can things, nice thing about the lamp and light act we can use to progress. We have to pay attention to the fact that in actuality I haven't taught you much, that you have by yourself ... decided on certain tasks and many of you have had prior knowledge. Clearly some information about light came up that was new ... someone knew about photons, while someone else mentioned two different types of wave theories which related to light. ... skipped the reviews about other already explained properties of light ...

So towards that goal, now that you have explained about light and it's properties ... it's time to move onto how to get a lamp to light up, so I looked up all of your get a lamp to light up, so llooked up all of your questions [considering how to make lamp light], do you remember when it was left in a mess underneath our line
diagram. I looked over them and combined them in lin $\mathrm{KF}$ view] into one rise above note.

Extract from Episode 28

Teacher: It's very important to remember all the observations you made earlier. And I was thinking that for that you need paper, a pen and someone with clean handwriting in your group, and then write down all the observations your team came up with. Agree with your group on who will be writing. I'm not sure if you need to bother writing straight to a computer, but that too is a possibility. The important part is conversing with your group. Are you listening Anne. Everyone speaks in turn and take your time in order to note everything down, of course you can speak if something comes up. The objective here is that you'd learn to design an test, that's what you're trying to think here. You probably remember from last year when you designed the test for the sugar cube to dissolve into water You designed it by yourself You had some some items and you designed yoursef. You has this is a similar assign you designed a Way to use them. This is a similar assignment. Begin from there, in order to be sue your questions are answered your specify on what your studying. Then write the tools you'll use and how you're planning on studying and to be sure that, that's what you want to investigate. We'l begin doing this during this class, one of you have a pen ready while the others go through the tools and write list of them.

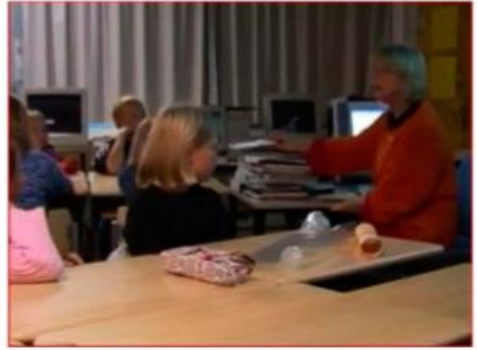

The teacher wants everybody to understand the present ongoing project phase.

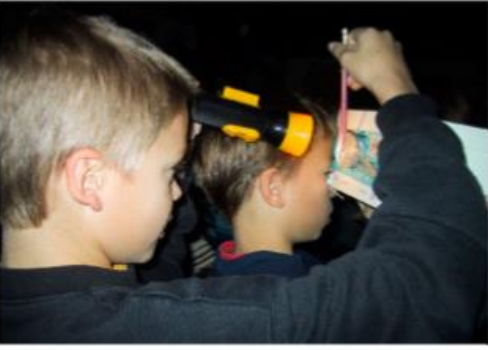

Experimenting with light after Episode 28.

$\begin{array}{ll}\text { Category and its definition } & \text { Extract from the orchestration event classified in the } \\ \text { category }\end{array}$

